6. Satapathy SK, Sclair S, Fiel Ml, Del Rio Martin J, Schiano T. Clinical characterization of patients developing histologically-proven fibrosing cholestatic hepatitis C post-liver transplantation. Hepatol Res 2011;41:328-339.

7. Delladetsima JK, Boletis JN, Makris F, Psichogiou M, Kostakis A, Hatzakis A. Fibrosing cholestatic hepatitis in renal transplant recipients with hepatitis $\mathrm{C}$ virus infection. Liver Transpl Surg 1999;5:294-300.

8. Evans $A T$, Loeb KR, Shulman HM, Hassan S, Qiu WC, Hockenbery DM, Ioannou GN, Chauncey TR, Gretch DR, McDonald GB. Fibrosing cholestatic hepatitis $\mathrm{C}$ after hematopoietic cell transplantation: report of 3 fatal cases. Am J Surg Pathol 2015;39:212-220.
9. Kyvernitakis A, Mahale P, Popat UR, Jiang $Y$, Hosry J, Champlin RE, Torres HA. Hepatitis $C$ virus infection in patients undergoing hematopoietic cell transplantation in the era of direct-acting antiviral agents. Biol Blood Marrow Transplant 2016;22:717-722.

10. Ziol M, Handra-Luca A, Kettaneh $A$, Christidis $C$, Mal F, Kazemi $F$, de Lédinghen $\mathrm{V}$, Marcellin $\mathrm{P}$, Dhumeaux $\mathrm{D}$, Trinchet $\mathrm{JC}$, Beaugrand $\mathrm{M}$. Noninvasive assessment of liver fibrosis by measurement of stiffness in patients with chronic hepatitis C. Hepatology 2005;41:48-54.

๑Copyright 2019 by Turkish Society of Hematology

Turkish Journal of Hematology, Published by Galenos Publishing House

\title{
Venous Thromboembolism in a Young Girl with Duplication of the Inferior Vena Cava and Protein S Deficiency
}

\author{
Vena Kava Inferior Dublikasyonu ve Protein S Eksikliği Olan Genç Kızda Venöz \\ Tromboemboli
}

\author{
(D) Wei-Li Liao1, (D) Ming-Yang Shih1, (D) Jiaan-Der Wang2,3 \\ ${ }_{1}^{1}$ Department of Pediatrics, Taichung Veterans General Hospital, Taichung, Taiwan \\ ${ }^{2}$ Center for Rare Disease and Hemophilia, Taichung Veterans General Hospital, Taichung, Taiwan \\ ${ }^{3}$ Tunghai University, Faculty of Medicine, Department of Pediatrics, Taichung, Taiwan
}

\section{To the Editor,}

A previously healthy 13-year-old girl presented with a 3-day history of progressive swelling and pain in her left lower limb. She also complained of cough in the last 2 weeks. No trauma, surgery, travel, or medication was noted before this illness. Physical examination revealed significant swelling and tenderness in her left lower limb. The laboratory data showed a high level of D-dimer ( $13.0 \mathrm{mg} / \mathrm{L} \mathrm{FEU,} \mathrm{reference} \mathrm{range}<0.55$ $\mathrm{mg} / \mathrm{L}$ FEU). Multidetector computed tomography showed extensive emboli formation from the left calf region to the left ilio-femoral veins and duplication of the inferior vena cava (IVC) (Figure 1). Pulmonary ventilation-perfusion (V/0) scintigraphy revealed several mismatched areas diagnostic for bilateral acute pulmonary embolism. Tracing the family history, her father had developed venous thromboembolism (VTE) at the age of 40 years and was diagnosed with protein $\mathrm{S}$ deficiency. A thrombophilia screening in this patient identified severe protein $S$ deficiency (protein S activity: 2\%, reference range: 55\%-140\%). Other results, including levels of homocysteine, antithrombin III, and protein C activity, were within normal limits; factor II G20210, factor V Leiden G1691A, anti-cardiolipin antibody, and anti- $\beta 2$ - glycoprotein I IgM and IgG were all negative. Her symptoms and signs subsided after treatment with heparin, followed by warfarin for 3 months. The repeated measurement of protein $\mathrm{S}$ activity was 7\% after discontinuation of treatment with warfarin for one week. Given that two provoking risk factors were present, the patient continued to receive prophylactic therapy with warfarin.

Virchow's triad describes the three main factors contributing to thrombosis, which include hypercoagulability, vessel injury, and venous stasis. Congenital anomalies of IVC may predispose to VTE due to resultant venous stasis. Duplication of IVC is usually considered as asymptomatic and an incidental finding while performing retroperitoneal surgery or venous interventional radiology. However, an increasing number of studies suggest that cases of unprovoked VTE were associated with duplication of the IVC $[1,2,3,4]$. The ages of these patients ranged from 18 to 84 years. No pediatric patient was reported.

VTE is long considered to be far less common in children than in adults. Most pediatric VTE is provoked and occurs with multiple risk factors [5]. Genetic risk factors play an important role in children who develop VTE and thrombophilia screening 

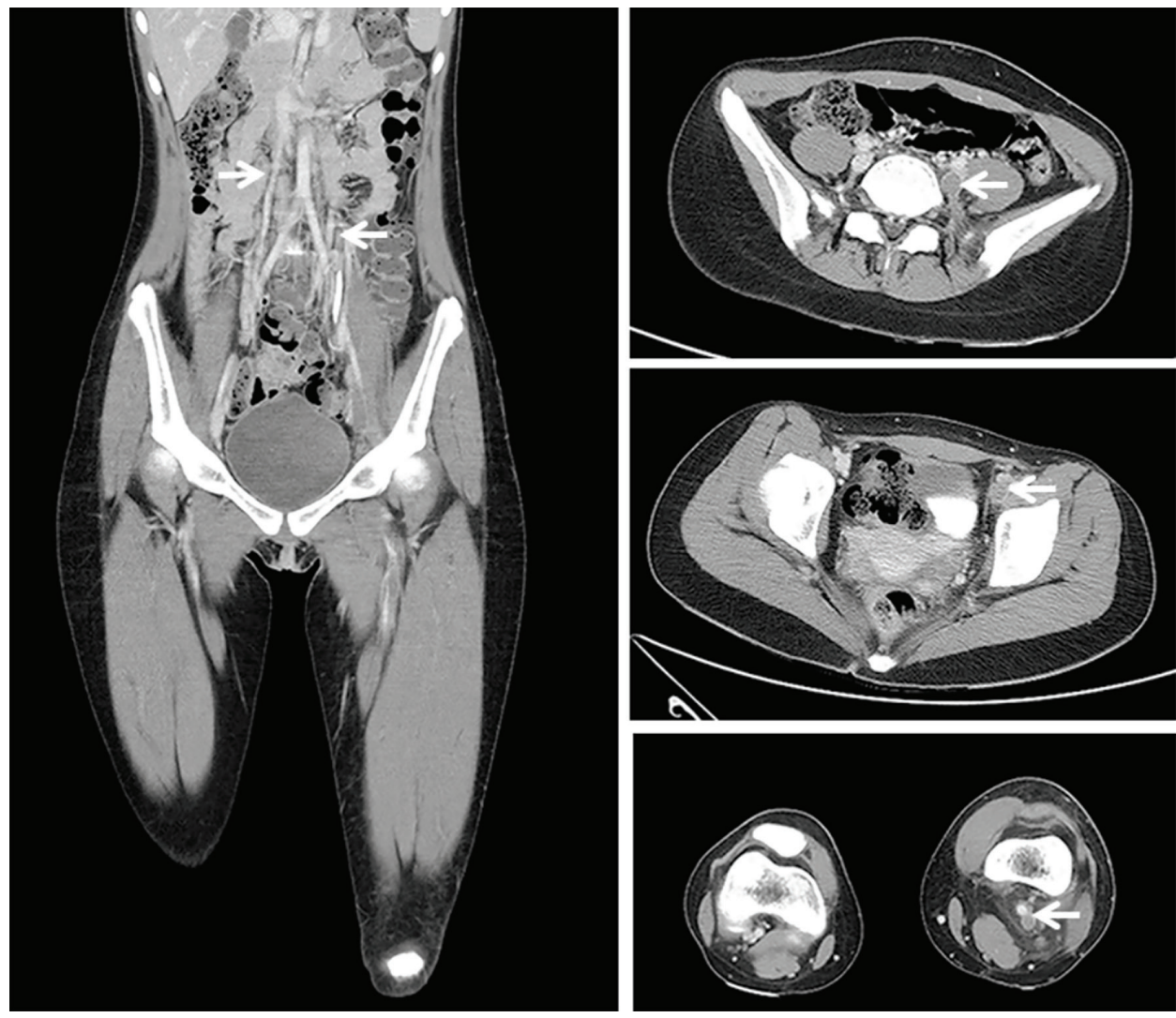

Figure 1. Left panel: Contrast-enhanced computed tomography image demonstrating duplicated inferior vena cava (whitish arrow). Right panel, from top to bottom: Arrow indicates thrombosis found in engorged left iliac vein, femoral vein, and popliteal vein. $254 \times 190 \mathrm{~mm}(72 \times 72 \mathrm{DPI})$.

is suggested in selected patients with VTE, such as young patients [6]. Protein S deficiency leads to loss of control of thrombin generation and fibrinolysis, and is associated with 5.8-fold increased odds of index VTE [7]. VTE in unusual sites has unique and obscure provoking factors [8]. Therefore, protein $\mathrm{S}$ deficiency was an important risk factor for the VTE event in this patient. In summary, we hypothesize that duplication of the IVC and protein S deficiency both promoted intravenous thrombus formation and predisposed the patient to develop VTE at a younger age. The combination of a rare congenital thrombophilic trait with a rare anatomic variant is very infrequent. In young patients with VTE less common causes of thrombosis such as inherited thrombophilias and anatomic abnormalities should be considered.

Keywords: Vena cava, Protein S deficiency, Venous thromboembolism

Anahtar Sözcükler: Vena kava, Protein S eksikliği, Venöz tromboemboli

Informed Consent: Received.

Conflict of Interest: The authors of this paper have no conflicts of interest, including specific financial interests, relationships, and/or affiliations relevant to the subject matter or materials included.

\section{References}

1. Anne N, Pallapothu R, Holmes R, Johnson MD. Inferior vena cava duplication and deep venous thrombosis: case report and review of literature. Ann Vasc Surg 2005;19:740-743.

2. Milani C, Constantinou M, Berz D, Butera JN, Colvin GA. Left sided inferior vena cava duplication and venous thromboembolism: case report and review of literature. J Hematol Oncol 2008;1:24.

3. Saad K, Saad P, Amorim CA, Armstrong D, de Freitas Soares BL, Neves PCF, Filho AR. Duplication of the inferior vena cava: case report and a literature review of anatomical variation. J Morphol Sci 2012;29:6064.

4. Lambert $M$, Marboeuf $P$, Midulla $M$, Trillot N, Beregi JP, MounierVehier C, Hatron PY, Jude B. Inferior vena cava agenesis and deep vein thrombosis: 10 patients and review of the literature. Vasc Med 2010;15:451-459.

5. Van Ommen $\mathrm{CH}$, Heijboer $\mathrm{H}$, Büller HR, Hirasing RA, Heijmans HS, Peters M. Venous thromboembolism in childhood: a prospective two-year registry in the Netherlands. J Pediatr 2001;139:676-681.

6. Colucci G, Tsakiris DA. Thrombophilia screening: universal, selected, or neither? Clin Appl Thromb Hemost 2017;23:893-899.

7. Young $G$, Albisetti $M$, Bonduel $M$, Brandao $L$, Chan $A$, Friedrichs $F$

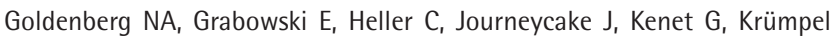
A, Kurnik K, Lubetsky A, Male C, Manco-Johnson M, Mathew P, Monagle $P$, van Ommen $H$, Simioni $P$, Svirin $P$, Tormene $D$, Nowak-Göttl U. Impact 
of inherited thrombophilia on venous thromboembolism in children: a systematic review and meta-analysis of observational studies. Circulation 2008;118:1373-1382.
8. Shatzel JJ, O'Donnell M, Olson SR, Kearney MR, Daughety MM, Hum J, Nguyen KP, DeLoughery TG. Venous thrombosis in unusual sites: A practical review for the hematologist. Eur J Haematol 2019;102:53-62.

\title{
A Successful Coronary Artery Bypass Operation with Intermittent Factor VIII Administration in a Hemophilia A Patient Who Was Admitted Due to Acute Myocardial Infarction: A Rare and Difficult Case
}

\author{
Akut Myokard Infarktüsü ile Başvuran Bir Hemofili A Hastasında Aralıklı Faktör VIII \\ Uygulamasılyla Başarı Sağlanabilen Koroner Arter Bypass Operasyonu: Nadir ve Zor Olgu
}

\author{
(D) Ulaş Serkan Topaloğlu1, (D) Rıfat Özmen², (D) Recep Civan Yüksel33, (D) Murat Çetin4, (D) Gülşah Akyol5 \\ ${ }^{1}$ Kayseri City Training and Research Hospital, Clinic of Internal Medicine, Kayseri, Turkey \\ ${ }^{2}$ Kayseri City Training and Research Hospital, Clinic of Cardiovascular Surgery, Kayseri, Turkey \\ ${ }^{3}$ Erciyes University Faculty and Medicine, Department of Internal Medicine, Intensive Care Unit, Kayseri, Turkey \\ ${ }^{4}$ Erciyes University Faculty and Medicine, Department of Cardiology, Kayseri, Turkey \\ ${ }^{5}$ Kayseri City Training and Research Hospital, Clinic of Hematology, Kayseri, Turkey
}

To the Editor,

There is not a large study in the literature other than a few case reports and reviews about the procedure of coronary artery bypass grafting surgery planned for patients with hemophilia. An internationally accepted definitive algorithm that recommends an approach to these patients was not included in the guidelines.

A 51-year-old male patient admitted in emergency service due to sudden and severe chest pain. He had no other medical history except hemophilia A. His electrocardiographic findings showed ST elevation in derivations II, III, and aVF. Troponin T at $0.19 \mathrm{ng} / \mathrm{mL}$ (normal: 0-0.1) was accepted as positive. The patient was admitted to the coronary intensive care unit with an initial diagnosis of acute inferior myocardial infarct and coronary angiography was urgently performed. Angiography revealed a moderate left ventricular ejection fraction (49\%) with three occluded coronary arteries. The left anterior descending artery was critically stenotic up to $80 \%$. The right coronary artery was stenotic up to 50\%. The circumflex coronary artery was also stenotic up to $90 \%$ (Figure 1). The patient received $50 \mathrm{U} / \mathrm{kg}$ (4000 U) factor VIII (FVIII) after angiography, which he was not able to receive before angiography due to the urgency of the case. Thereafter, he received $25 \mathrm{U} / \mathrm{kg}$ (2000) FVIII twice a day for 3 days, and then $20 \mathrm{U} / \mathrm{kg}(1600 \mathrm{U})$ FVIII was given for the following 7 days at intervals of $12 \mathrm{~h}$. No intervention was performed during angiography because of multi-vessel disease and bypass operation was decided. Among blood parameters tested during admission of the patient, the activated partial thromboplastin time (aPTT) was $51.4 \mathrm{~s}$. The FVIII inhibitor test was negative. His childhood FVIII level was 11.3; thus, he was evaluated as having a mild case of hemophilia A.

Prior to the bypass operation, the patient received $50 \mathrm{U} / \mathrm{kg}$ (4000 U) FVIII replacement and was taken to the operation with an aPTT value of $45.6 \mathrm{~s}$. The bypass operation was carried out with the same procedures as for non-hemophiliac patients including standard heparinization. In order to prevent disseminated intravascular coagulation during factor replacements of the patient, heparin was not used except for a pump procedure. After the patient was weaned from the cardiopulmonary pump, $50 \mathrm{U} / \mathrm{kg}(4000 \mathrm{U})$ bolus FVIII was administered. For the following 3 days, $25 \mathrm{U} / \mathrm{kg}(2000 \mathrm{U}) \mathrm{FVIII}$ was administered at intervals of $12 \mathrm{~h}$. Thereafter, $20 \mathrm{U} / \mathrm{kg}(1600 \mathrm{U})$ FVIII was administered for 7 days at intervals of $12 \mathrm{~h}$ (Table 1). The patient has been followed for 3 years with routine controls. Within this period, he has had no serious medical problems except nosebleeds.

When the literature was analyzed, it was identified that continued infusion of FVIII was rarely administered in pre- 